Ashil: Jurnal Pendidikan Anak Usia Dini

Vol. 1 No. 1, April 2021. e-ISSN: 2776-4117

https://doi.org/10.33367/piaud.v1i1.1564

Journal Ashil

Submitted: $\quad$ Revised:

04-02-2021

22-03-2021

Accepted:

Published:

23-04-2021

24-04-2021

\title{
Peningkatan Kualitas Pembelajaran Anak Usia Dini melalui Pemanfaatan Lingkungan Sekitar sebagai Sumber Belajar
}

\author{
Miftah Kusuma Dewi \\ IAI Pangeran Diponegoro Nganjuk \\ miftakusuma978@gmail.com
}

\begin{abstract}
Abstrak
Anak usia dini adalah masa yang sering disebut dengan masa keemasan untuk tumbuh dan berkembang sesuai dengan tingkat usianya secara cepat dan hebat. Dalam masa ini, anak dididik dengan memberikan stimulus, bimbingan pengasuhan dan pemberikan kegiatan-kegiatan yang perpusat untuk mengembangkan kemampuan dan ketrampilan anak. Proses pembelajaran anak usia dini yang menyenangkan, menarik dan efektif bagi anak dipengaruhi oleh beberapa unsur diantaranya adalah harus tersedianya sumber belajar yang dapat menunjang kegiatan pembelajaran. Sumber belajar pada proses pembelajaran anak usia dini mempunyai peran yang penting untuk keberhasilan dan tercapainya perkembangan yang diharapkan. Permasalahan yang sering muncul di lembaga pendidikan adalah kurangnya ketersediaan sumber belajar yang dimiliki. Oleh karena itu, guru diharapkan lebih kreatif untuk memanfaatkan lingkungan sekitar sebagai sumber belajar untuk meningkatkan dan mengefektifkan pembelajaran. Topik ini penting untuk dikaji karena pemanfaatan lingkungan sekitar sebagai sumber belajar merupakan salah satu aspek yang harus diperhatikan pendidik anak usia dini supaya pembelajaran menjadi menarik dan efektif.. Penelitian ini menggunakan metode penelitian studi pustaka atau library research. Data dalam penelitian ini berupa manuskrip dan buku yang semuanya bersumber dari khazanah pustakawan.dan hasil dari penelitian ini bertujuan agar pendidik dan siswa memahami bahwa lingkungan sekitar sebagai sumber belajar menyedikan berbagai hal yang dapat dimanfaatkan dan dipelajari anak untuk menambah wawasan serta pengetahuan yang tidak mereka dapatkan di ruang kelas
\end{abstract}

Kata kunci: Anak Usia Dini, Sumber Belajar, Lingkungan Sekitar

\begin{abstract}
Early childhood is a period that is often called the golden age to grow and develop according to age levels quickly and greatly. In this period, children are educated by providing stimulus, parenting guidance and providing activities that are centered on developing children's abilities and skills. The learning process of early childhood which is fun, interesting and effective for children is influenced by several elements, including the availability of learning resources that can support learning activities. Learning resources in the early childhood learning process have an important role in the success and achievement of expected development. The problem that often arises in educational institutions is the lack of available
\end{abstract}


learning resources. Therefore, teachers are expected to be more creative in utilizing the surrounding environment as a learning resource to improve and make learning effective. This topic is important to study because the use of the surrounding environment as a source of learning is one aspect that early childhood educators must pay attention to so that learning becomes interesting and effective. This study uses a library research research method or library research. The data in this study are in the form of manuscripts and books, all of which are sourced from librarian treasures. And the results of this study aim that educators and students understand that the surrounding environment as a learning resource provides various things that children can use and learn to add insight and knowledge that they do not get in the classroom.

Keyword: Early Childhood, Learning Resources, The Environment

\section{PENDAHULUAN}

Anak usia dini adalah salah satu individu yang memiliki masa pertumbuhan dan perkembangan sesuai dengan tahapan yang dilaluinya. Anak usia dini berada pada rentang usia 0 - 6 tahun. Sujiono dalam bukunya Bermain Kreatif Berbasis Kecerdasan Jamak menjelaskan bahwa pada usia ini proses pertumbuhan dan perkembangan anak sedang mengalami masa yang cepat dalam rentang perkembangan hidup manusia. Oleh karena itu, usia dini sebagai usia emas (Golden age), dimana anak sangat berpotensi banyak hal dengan cepat (Sujiono \& Nurani, 2013).

Masa ini merupakan masa peletakan landasan bagi perkembangan fisik dan motorik, kognitif, bahsa, sosial emosional, seni, moral dan nilai-nilai agama. Peraturan Pemerintah nomor 58 tahun 2009 ada dua aspek bidang pengembangan yang dijabarkan yaitu: 1) Bidang pengembangan perilaku anak atau pembiasaan yang meliputi : agama, moral, sosial emosional dan kemandirian; 2) Bidang kemampuan dasar, meliputi : bahasa, kognitif, dan fisik motorik. Pengembangan tersebut diberikan untuk persiapan memasuki pendidikan dasar (Suyanto, 2005).

Untuk mengoptimalkan perwujudan tujuan pendidikan, maka proses pembelajaran harus dirancang dan disesuaikan dengan tahap perkembangan dan karakteristik belajar anak. Setiap anak yang memiliki potensi besar untuk mengoptimalkan semua aspek perkembangan terutapa pada usia 2-6 tahun. Perkembangan kognitif anak pada usia tersebut berkembang sangat pesat. Dalam Penelitian Keith Osbom dkk menyebutkan bahwa perkembangan intelektual anak 
terjadi sangat pesat pada awal kehidupan anak. Ketika seorang anak berusia 4 tahun, sekitar $50 \%$ variasi kecerdasan orang dewasa telah terjadi. Kemudian meningkat $30 \%$ pada usia 8 tahun, menyisakan $20 \%$ di pertengahan atau akhir dekade kedua (Kemdiknas, 2010).

Untuk menunjang sebuah proses pembelajaran pendidikan anak usia dini yang efektif adanya sebuah terobosan terbaru dalam ketersediaan media pembelajaran, sumber belajar dan fasilitas yang lengkap dan mengikuti perkembangan kemajuan teknologi. Ketersediaan media dan sumber belajar yang memadai dapat memfasilitasi peserta didik dalam mengembangkan potensinya dalam berbagai aspek perkembangan seperti nilai agama dan moral, fisik morotik, bahasa, kognitif, sosial emosional dan seni.

Dalam efektifitas pembelajaran, guru dan lembaga PAUD sering dihadapkan dengan kurang tersediaanya media dan sumber belajar yang dipadang kurang. Tidak hanya itu, fasilitas pembelajaran seperti tempat bermain yang ada di ruang kelas terkadang dirasa kurang memadai untuk mengembangkan potensi anak didiknya. Media pembelajaran dan sumber belajar dikatakan cukup dan memadai untuk peserta didik jika kedua komponen tersebut dapat digunakan anak didiknya secara bergantian sesuai dengan jumlah siswa yang ada dalam sebuah lembaga. Untuk itu perlu adanya solusi agar proses pembelajaran dapat berjalan sesuai dengan perencanaan dan juga kurikulum yang telah dibuat.

Media dan sumber belajar untuk anak usia 2-6 tahun sebenarnya sangat beragam, tidak hanya yang dibuat pabrik atau yang memiliki haarga mahal, tetapi guru bisa memanfatkan bahan yang ada disekitar anak dan membuatnya dari bahan tersebut. Begitu juga dengan kekurangan ruang untuk kegiatan pembelakaran. Maka, lingkungan sekitar merupakan solusi tempat yang sangat tepat dan paling menyenangkan untuk bermain anak dan mampu mengefektifkan pembelajaran.

Hendrawati, Endah berpendapat bahwa sumber belajar lingkungan dapat meningkatkan aktivitas dan prestasi peserta didik, membuat peserta didik peka terhadap masalah sosial yang terjadi di masyarakat, pandai mengatasi setiap masalah yang terjadi di masyarakat, serta dapat megembakan pengetahuan, 
keterampilan, sikap dan nilai untuk berpartisipasi dalam kehidupan (Hendrawati, 2013).

Berdasarkan uraian di atas, maka penulis akan membahas tentang Peningkatan Kualitas Pembelajaran Anak Usia Dini melalui Pemanfaatan Lingkungan Sekitar sebagai Sumber Belajar. Dan manfaat dari penelitian ini adalah pendidik mampu memanfaatkan lingkungan sekitar sebagai sumber belajar agar kualitas pembelajaran Anak Usia Dini meningkat.

\section{METODE}

Jenis penelitian yang digunakan penulis pada saat penulisan artikel ini adalah studi pustaka atau library research. Data dalam penelitian ini berupa manuskrip dan buku yang semuanya bersumber dari khazanah pustakawan.

Tekhnik pengumpulan data dengan melakukan penelaahan terhadap buku tersebut, literature, catatan, jurnal, web (internet). Penulis menggunakan tehnik ini dalam rangka mengumpulkan data yang berkaitan dengan peningkatan kualitas pembelajaran anak usia dini melalui peningkatan sekitar s ebagai sumber belajar.

Teknik analisis data menggunakan analisis isi (content analysis) dengan menarik kesimpulan tentang topik yang disajikan dalam artikel ini dari berbagai sumber. Langkahnya adalah dengan memilih teks yang akan ditulis dan menyusun beberapa item tertentu yang akan diteliti.

\section{HASIL DAN PEMBAHASAN}

Pembelajaan Anak Usia Dini

Pembelajaran anak usia 2-6 tahun merupakan proses interaksi antara anak, orang tua atau orang dewasa lainnya di lingkungannya untuk mencapai tugastugas perkembangannya. Interaksi yang terjalin merupakan faktor yang mempengaruhi pencapaian tujuan pembelajaran (Akbar, 2020). Dalam sebuah interaksi itu merupakan cerminan dari suatu hubungan yang erat, berkaitan dan berkesinambungan antara anak, orang tua, guru dan pembelajaran yang beragam. Dengan demikian proses pembelajaran dapat berjalan menarik serta peserta didik dapat memperoleh pengalaman baru. 
Pada dasarnya proses belajar mengajar pada usia dini merupakan pembelajaran yang diberikan pada anak usia dini agar dapat berkembang secara berkesinambungan atau sesuai dengan umurnya. Pembelajaran adalah belajar sambil bermain, dimana anak aktif dalam berbagai kegiatan untuk memperoleh pengalaman baru di lingkungan baru. Oleh karena itu, permainan merupakan bagian dari proses pembelajaran.

Dalam Peraturan Pemerintah no 19 tahun 2005 bab IV pasal 19 dikatakan bahwa proses pembelajaran pada satuan pendidikan diselenggarakan secara interaktif, inspiratif, menyenangkan, menantang dan memotivasi anak didik untuk berpartisipasi akitf serta memberikan ruang yang cukup bagi prakarsa, kreativitas dan kemandirian sesuai dengan bakat, minat dan perkembangan fisik serta psikologi anak didik (PP, 2007).

Berdasarkan peraturan tersebut menjelaskan bahwa proses pembelajaran memiliki sejumlah prinsip yang harus dipenuhi. Asmiranda.P mengatakan prinsip dalam proses pembelajaran adalah sebagai berikut:

1. Interaktif

Prinsip interaktif dalam mengajar tidak hanya untuk menyampaikaan pengetahuan dari pendidik kepada peserta didik, tetapi juga mengajar dianggap sebagai suatu proses pengaturan lingkungan yang dapat merangsang peserta didik untuk belajar. Oleh karena itu, kemampuan siswa dapat berkembang secara mental, spiritual, intelektual, emosional, sisial dan fisik.

2. Inspriratif

Proses pembelajaran yang inspiratif merupakan proses pembelajaran dimana peserta didik dapat berusaha melakukan sesuatu. Dalam proses pembelajaran, pendidik harus membuka segala macam kesempatan agar peserta didik dapat melakukan sesuatu yang berhubungan dengan materi pembelajaran. Merangsang motivasi anak untuk mengembangkan inspirasinya sendiri, sehingga keterampilan dan pengalaman pengetahuannya dapat berkembang secara mandiri dan menjadi lebih bermakna dan konstekstual 
3. Menyenangkan

Untuk proses pembelajran yang menarik atau bermakna, pendidik dapat melakukan beberapa hal salah satunya adalah dengan menata ruang kelas dan mengelola berbagai kegiatan pembelajaran yang bervariasi.

4. Menantang

Menantang dapat dijelaskan sebagai proses pembelajaran yang memungkinkan siswa ditantang mengembangkan kemampuaannya dalam berpikir, keterampilan aplikatif dan keterampilan sosial

5. Memotivasi

Memotivasi merupakan daya dorong yang diberikan pendidik kepada anak didiknya untuk bertindak atau melakukan sesuatu (Parapat, 2020).

Kegiatan belajar untuk anak usia 0 sampai 2 tahun merupakan kegiatan belajar yang mudah untuk diingat dan dilakukan setiap hari. Misalnya diperkenalkan berbagai bentuk, berbagai binatang, buah-buahan dan berbagai benda. Antara usia 3 dan 6 tahun, bentuk aktivitasnya hampir sama dengan usai sebelumnya, namun lebih ditekankan pada kegiatan sosial antar manusia dan menanamkan rasa cinta dan kerjasama antar teman Metode-metode dalam pembelajaran PAUD, antara lain :

1. Metode Bermain

Metode bermain merupakan metode dengan menggunakan jenis permainan tertetu sebagai wahana pembelajaran peserta didik. "Bermain yang tepat adalah setiap kegiatan yang dilakukan untuk kesenangan yang ditimbulkan tanpa mempertimbangkan hasil akhir. Kegiatan bermain dilakukan dengan sukarela dan tanpa ada paksaan atau tekanan dari luar atau kewajiban" ungkap Hurlock (Hurlock, 2011)

2. Metode Bercerita

Nurbiana Dhieni dkk, dalam bukunnya Metode Pengembangan Bahasa.mengatakan metode bercerita adalah penyajian materi atau cara penyampaian pembelajaran cera lisan dari guru kepada peserta didik dalam 
bentuk cerita di Taman Anak-anak. Adapun pelaksanaan pembelajaran tersebut berusaha memperkenalkan, memberikan informasi atau penjelasan tentang hal-hal baru untuk menyampaikan hasil belajar. Dengan cara ini berbagai kemampuan dasar anak dapat dikembangkan (Dhieni dkk, 2008).

3. Metode Bernyanyi

Merupakan suatu metode pembelajaran dengan menggunakan nyanyian sebagai wahana belajar siswa dalam proses belajar mengajar. Metode ini biasannya lagu yang dinyanyikan disesuaikan dengan materi yang diajarkan.

Pembelajaran dengan bernyanyi membuat suasana kelas menjadi riang, menyenangkan dan siswa lebih bersemangat. Sehingga proses belajarnya tidak membosankan. Selain itu, peserta didik sangat suka bernyanyi dan bertepuk tangan serta menari. Oleh karena itu, pembelajaran dengan menggunakan metode bernyanyi mampu meningkaatkan siswa dalam perkembangannya.

4. Metode Karyawisata

Metode ini merupakan suatu metode yang paling digemari mulai dari anak-anak sampai orang dewasa. Metode ini adalah metode karyawisata, dimana cara mengajarnya dilaksanakan dengan mengajak peserta didik ke suatu tempat atau obyek tertentu diluar sekolah yang disesuaikan dengan tema yang dipelajari. Seperti, perkebunan, swalayan, pasar, kantor pemadam kebakaran dan lain sebagainya.

5. Metode bercakap-cakap

Metode bercakap-cakap merupakan kegiatan berdialog berupa mengobrol atau bertanya dan menjawab pertanyaan antara anak dengan guru atau antara anak dengan teman-temannya. Cara ini bisa dilakukan dengan bentuk dialog bebas, dialog berdasarkan tema, dan dialog berdasarkan gambar berseri

6. Metode Demonstrasi

Metode demonstrasi merupakan metode yang dilakukan melalui latihan atau peragaan keterampilan tertentu dengan tujuan agar peserta didik mampu memahami kegiatan tersebut. Misalnya, kegiatan meniup balon, menggosok 
gigi, mencuci tangan, membuat minuman, menanam bunga dan lain sebagainya.

Proses pembelajaran pada usia anak dini (PAUD) diawali dengan mengerti dan memahami karakter setiap anak, yang mana setiap siswa mempunyai pengetahuan, pemahaman yang berbeda-beda. Oleh karena itu, proses belajar mengajar pada anak usia dini harus memperhatikan perkembangan anak, kebutuhan anak, belajar sambil bermain, pendekatan tematik, kreatif, inovatif, metode pembelajaran yang bervariasi, lingkungan yang kondusif dan selalu mengembangkan kecakapan hidup.

Sumber Belajar dari Lingkungan Sekitar

Sumber belajar berasal dari dua kata yaitu sumber dan belajar. Sumber dikenal dengan istilah asal, asal usul, bahan. Sedangkan belajar adalah proses mencari pengalaman, ilmu dan berubah tingkah laku.

Menurut Warsito B mengatakan bahwa sumber belajar adalah suatu sistem yang terdiri dari sekumpulan bahan atau situasi yang diciptakan dengan sengaja dan dibuat agar memungkinkan peserta didik secara individual (Warsito, 2008).

Dalam kesempatan yang sama, Nana Sudjana dan Ahmad Rivai menyampaikan bahwa sumber belajar merupakan sumber daya yang dapat digunakan secara langsung maupun tidak langsung, baik sebagian maupun selurunya dalam proses pembelajaran (Sudjana \& Rivai, 1989).

Asosiasi Pendidikan Komunikasi dan Teknologi Pendidikan (Association for Educational Communication and Technology) dalam Daryanto menjelaskan tentang pengertian sumber belajar adalah sumber baik berupa data, orang dan wujud tertentu yang dapat digunakan oleh siswa dalam belajar baik secara terpisah maupun secara terkombinasi. Sehingga, memudahkan peserta didik dalam mencapai tujuan belajarnya (Daryanto, 2016).

Dari beberapa pendapat di atas dapat disimpulkan bahwa pengertian sumber belajar adalah segala sesuatu yang dapat digunakan untuk menunjang proses belajar mengajar baik berupa manusia, hewan, benda, tumbuhan dan 
keadaan tertentu. Dengan demikian peserta didik dapat memanfaatkannya sebagai sumber kegiatan belajar dan dapat meningkatkan kualitas pembelajaran

Daryanto mengatakan bahwa menurut beberapa sudut pandang, sumbee belajar dibedakan menjadi beberapa jenis. Artiya, sumber belajar dilihat dari jenis atau asalnya dibedakan menjadi dua jenis, yaitu sumber belajar yang dirancang dan sumber belajar yang mudah tersedia.

Adapun penjelasannya dari pengertian sumber belajar diihat dari asal usulnya antara lain :

1. Sumber belajar yang dirancang (Learning Resources by Design)

Merupakan sumber belajar yang sengaja digunakan untuk tujuan mengajar. Oleh karena itu, dasar dari perancangan tersebut adalah isi, tujuan, tema dan karakteristik siswa tertentu. Sumber belajar ini sering disebut dengan bahan intruksional (instructional materials). Misalnya, materi pembelajaran terprogram, modul, transparansi produk tertentu, slide untuk mata pembelajaran tertentu, guru mata pelajaran, film tentang topik pembelajaran tertentu, video khusus, pengajaran komputer.

2. Sumber belajar yang mudah tersedia (Learning Resources by Utilization)

Merupakan sumber belajar yang telah tersedia, maksudnya nonintruksional, tetapi dapat digunakan sebagai sumber belajar dengan kualitas yang sama dengan jenis by design. Misalnya, taman safari, taman raya, kebun nasional, museum bahari, museum wayang, slide tentang kota New York, buku biografi (Daryanto, 2016)

Selanjutnya, Asosiasi Pendidikan Komunikasi dan Teknologi Pendidikan (Association for Educational Communication and Technology) Dijelaskan dalam Daryanto bahwa sumber belajar dibagi menjadi 6 jenis yaitu pesan, peonal, materi, alat, teknologi dan lingkungan.

Sumber belajar yang mudah tersedia dapat diartikan dengan sumber belajar dari lingkungan sekitar. Lingkungan ini dapat dimanfaatkan untuk mengefektifkan kegiatan pendidikan anak usia dini sepanjang relevan dengan tingkat usia baik berupa lingkungan alam, lingkungan sosial dan lingkungan budaya. Lingkungan sekitar anak merupakan salah satu sumber belajar yang dapat 
dioptimalkan untuk mencapai proses dan hasil pendidikan anak usia dini yang berkualitas.

Lingkungan menyediakan berbagai macam hal untuk anak-anak, mereka dapat belajar dan memberikan pengalaman baru. Jumlah sumber belajar yang ada disekitar mereka tidak terbatas, meskipun sumber belajar tersebut tidak sengaja dirancang untuk tujuan pendidikan. Kemudian sumber belajar di lingkungan ini akan semakin memperkaya keilmuan dan pengetahuan anak, karena pembelajaran mereka tidak dibatasi oleh empat dinding kelas ('Ulum, 2014).

Proses pembelajaran dengan memanfatkan lingkungan yaitu lingkungan sekitar alam sebagai sumber belajar anak. Contohnya air, hutan, tanah batu-batu, sungai, tumbuhan dan hewan baik flora maupun fauna, sungai, iklim, suhu dan sebagainya jauh lebih terkesan terhadap peserta didik dikarenakan mereka dihadapkan langsung pada lingkungan serta serta situasi yang sebenarnya.

Di samping lingkungan alam, lingkungan sosial disekitar anak juga dapat dimafaatkan sebagai sumber belajar bagi peserta didik seperti keberagaman agama, adat istiadat, kesenian daerah, macam-macam pekerjaan serta organisasi msyarakat dan kebiasaan masyarakat. Hal ini dapat menambah wawasan anak tentang pentingnya mengenal kebudayaan lokal.

Nilai dan manfaat berbagai sumber daya alam dapat dijadikan sebagai literasi sumber belajar untuk mendidik anak usia dini . Oleh karena itu semoga kreativitas dan jiwa inovatif pendidik dapat dimunculkan dan meraka mampu bekerjasama dengan lingkungan melalui metode pembelajaran, sehingga proses pembelajaran menjadi menarik bagi siswa dan menyenangkan.

Peningkatan Kualitas Pembelajaran Anak Usia Dini melalui Pemanfaaatan Lingkungan Sekitar sebagai Sumber Belajar

Peningkatan kualitas pembelajaran agar sesuai dengan proses pembelajaran yang tertulis dalam Peraturan Pemerintah nomor 19 tahun 2005 bab IV pasal 19 maka pembelajaran harus dibuat menyenangkan, menantang, membuat bersemangat dan berkesan bagi anak. Pembelajaran yang 
menyenangkan untuk anak usia dini adalah ketika mereka belajar langsung dengan lingkungannya.

Untuk membuat pembelajaran yang menyenangkan diperlukan sebuah gagasan, sebuah terobosan dalam pembelajaran tersebut seperti sumber belajar yang sesuai. Sumber belajar memiliki peran stategis yang lebih luas dibandingkan media pembelajaran. Sumber belajar sangat penting dalam proses pembelajaran dan dalam menumbuhkan potensi dan kreativitas anak.

Permasalahan yang sering dialami pendidik dalam proses belajar mengajar adalah keterbatasan sumber belajar di lembaga tersebut seperti kekurangan buku dan APE yang dimiliki untuk dapat dimainkan anak secara bergantian. Oleh karena itu, lingkungan adalah sahabat terbaik dalam mengatasi permasalahan tersebut.

Sebagaimana permasalahan yang telah dipaparkan di atas, lingkungan memiliki beragam fasilitias yang dapat dimanfaatkan pada waktu kegiatan belajar mengajar. Lingkungan kita terbagi menjadi lingkungan alam dan lingkungan sosial. Segala hal yang ada dilingkungan dalam dapat kita gunakan sebagai sumber belajar anak begitu juga kejadian yang terangkum pada lingkungan sosial.

Pemanfaatan lingkungan sekitar sebagai sumber belajar merupakan hal yang dapat meningkatkan proses pembelajaran. Kita dapat mengambil sebuah contoh yaitu ketika kegiatan membuat kreasi dari manik-manik dan guru kekurangan bahan, maka guru dapat memanfaatkan biji-bijian yang terdapat dari alam. Tidak hanya itu, pada saat kegiatan seni dan guru kekurangan alat musik, maka guru dapat membuat alat musik sendiri yang terbuat dari bahan lingkungan sekitar seperti terompet dari batang daun papaya atau mengisi botol dengan kerikil dan biji-bijian yang ada.

Sumber belajar dari lingkungan sosial yang dapat digunakan adalah pengenalan lingkungan. Contohnya pengenalan mata pencaharian mayarakat sekitar yaitu sebagai petani, peternak, pedagang, guru, polisi dan lain-lain. Pada saat pembelajaran tema tentang profesi, maka anak diajak ke perkebunan untuk mengetahui profesi masyarakat sebagai petani buah dan tanaman bunga. Di kebun mereka diberikan sebuah pengalaman belajar tentang bagaimana cara menanam, 
memupuk dan memanen buah. Peserta didik diajak terjun langsung kelapangan untuk menanam pada bersama para petani kebun.

Dan yang tidak kalah penting dari pemanfaatan lingkungan sebagai sumber belajar adalah untuk meningkatkan pembelajaran pada anak usia dini dalam mengenal, memahami dan memafaatkan lingkungan sekitar mereka. Salah satuny a kegiatan mengenal flora dan fauna. Peserta didik diajak untuk mengunjungi peternakan milik warga sekitar seperti peternaka sapi, ayam, kambing, ikan lele dan gurame. Mereka diperlihatkan bagaimana caranya memberi makan pada hewan yang ada dipeternakan, selain itu juga disampaikan tentang pentingnya merawat dan menyayangi binatang.

Kemudian pengenalan budaya lokal juga tidak kalah pentingnya seperti adat istiadat dalam berpakaian, lagu daerah, permainan daerah dan tari daerah lain yang mana siswa diajarkan dan dikenalkan adat istiadat lingkungan disekitar meraka.

Pengenalan-pengenalan ini dirasa sangat penting dikarenakan perkembangan zaman yang semakin canggih dan maju, sehingga para peserta didik diharapakan mampu menjaga, merawat dan melestarikan adat istiadat sebagai kearifan lokal agar tidak hilang atau punah.

Sumber belajar dari lingkungan merupakan pembelajaran yang nyata bagi peserta didik. "Salah satu azas pembelajaran / diktaktik pembelajaran anak usia dini adalah prinsip kekongkritan atau keperagaman dalam arti pembelajaran anak harus menyuguhkan pengalaman-pengalaman belajar yang nyata sehingga anak memperoleh pegalaman belajar yang bermakna (meaningfuh)" ungkap Badruzzaman. Selain itu sarana dan prasarana yang dapat memberikan pengalaman belajar yang bermakna adalah media atau sumber belajar yang dipilih dan dihasilkan oleh guru secara kreatif (Badruzzaman, 2020).

Manfaat dari pemanfaatan lingkungan sekitar sebagai sumber belajar adalah membantu menjelaskan hal-hal sulit yang terdapat dibuku, menyediakan pengelaman baru, menghemat biaya pengadaan APE, mengembangkan kreativitas anak, membantu keterbatasan lambat belajar, dan memberikan motivasi anak untuk selalu belajar. 
Sebagaimana diungkapkan Chiri bahwa belajar pada lingkungan sangat meningkatkan wawasan pengetahuan tentang pengetahuan anak. Karena tidak hanya mempelajari pengetahuan kognitif saja, tetapi juga secara keseluruhan. Di lingkungan anak belajar sikap (emosi), tentang cara menumbuhkan toleransi, saling menghormati, saling membantu dan lain-lain. Oleh karena itu, pembelajaran dengan cara ini akan meningkatkan sikap sosial terhadap masyarakat. Selain itu, pembelajaran di lingkungan akan meningkatkan keterampilan anak (aspek psikomotorik). Misalnya melalui kegiatan praktek (latihan) dan observasi, maka anak akan langsung memahami dan mengalaminya (Choiri, 2017).

Oleh karena itu dapat dikatakan bahwa lingkungan sekitar memberikan berbagai hal yang dapat digunakan untuk belajar yang tidak terbatas bagi anakanak. Meski tidak sengaja dirancang untuk tujuan pendidikan, sumber belajar dari lingkungan sekitar akan semakin memperkaya wawasan dan pengetahuan anak, karena dapat mengoptimalkan potensi panca indera untuk berkomunikasi dengan lingkungan. Karena lingkungan menyediakan berbagai sumber belajar, dan sangat beragam, maka pembelajaran terus meningkat dan menarik bagi anak-anak.

\section{SIMPULAN}

Dari hasil analisa dan diskusi pembahasan dapat ditarik kesimpulan bahwa:

Lingkungan sekitar memberikan berbagai hal yang dapat dipelajari oleh anak dengan jumlah tidak terbatas baik dalam lingkungan alam dan lingkungan sosial. Sumber belajar dari lingkungan sekitar dapat memperkaya wawasan dan pengetahuan anak, karena dapat mengoptimalkan potensi panca indera untuk berkomunikasi secara langsung dengan lingkungannya. Dengan memanfaatkan sumber belajar dari linkungan sekitar maka pembelajaran akan semakin menarik dan efektif. Pembelajaran juga semakin meningkat disebabkan karena lingkungan sekitar sebagai sumber belajar menyediakan berbagai macam pilihan.

Pemanfaatan lingkungan sekitar sebagai sumber belajar adalah meningkatkan prestasi belajar, siswa dapat belajar mandiri, membantu menjelaskan hal-hal sulit yang terdapat pada buku, menyediakan pengalaman baru, memberikan suasana yang unik bagi siswa, mengatai kebosanan dalam 
belajar, menghemat biaya, pengadaan APE, mengembangkan kreatifitas anak, membantu keterbatasan tempat pembelajaran dan memberikan motivasi anak untuk selalu belajar.

\section{REFERENSI}

Akbar, Eliyyil. (2020). Metode Belajar Anak Usia Dini. Jakarta: Kencana Badruzzaman, "TATULAR: Upaya Meningkatkan Kualitas Pembelajaran AUD" Diakses pada http://pgpaud.upi.edu/tatular-upaya-meningkatkan-kualitaspembelajaran-aud/tanggal 1 Desember 2020

Bambang Warsita. (2008). Teknologi Pembelajaran. Jakarta: Renika Cipta Daryanto. (2016). Belajar dan mengaja. Bandung : Yrama Widya

Dhieni, Nurbiana dkk. (2008). Metode Pengembangan Bahasa. Jakarta: Universitas Terbuka

Direktorat Jenderal Pendidikan Islam Departemen Agama RI. (2007). Kumpulan Undang-Undang dan Peraturan Pemerintah RI tentang Pendidikan

Hendrawati, Endah. (2013). Pengaruh pemanfaatan lingkungan sebagai sumber belajar melalui metode inkuiri terhadap hasil belajar siswa SDN I Sribit Delanggu pada pelajaran IPS. PEDAGOGIA. Jurnal Pendidikan, 2(1)

Harlock, Elizabeth B. (2011). Psikologi Perkembangan: Suatu Pendekatan Sepanjang Rentang Kehidupan, Jakrta: Gramedia Pustaka

Kemdiknas. (2010). Tingkat Pencapaian Perkembangan Anak TK. Jakarta: Kemdiknas RI

Miftahul, Moh. Choiri. (2017). Upaya Pemanfaatan Lingkungan Sekitar Sebagai Sumber Belajar Anak. Jurnal Refleksi Edukatika 8 (1)

Parapat, Asminandar (2020). Srategi Pembelajaran Anak Usia Dini. Tasikmalaya: Edu Publiser

Sudjana, Nana. Ahmad Rivai. (1989). Teknologi Pengajaran. Bandung: Sinar Baru

Sujiono, Yuliani Nurani. (2013). Bermain Kreatif Berbasis Kecerdasan Jamak. Jakarta: Indeks

Suyanto, dkk. (2005). Bermain dan Permainan Anak. Jakarta: universitas Terbuka 
Miftah Kusuma Dewi

Peningkatan Kualitas...

'Ulum, Irfatu. (2014). Pemanfaatan Lingkungan Sebagai Sumber Belajar Anak. Jurnal Pendidikan Anak, Vol 3, No. 2 